\title{
REINTRODUCTION OF THE PRZEWALSKI'S HORSE IN CHINA: STATUS QUO AND OUTLOOK
}

\author{
Zhigang Jiang ${ }^{1,2}$, Hao Zong ${ }^{3}$ \\ ${ }^{1}$ Institute of Zoology, Chinese Academy of Sciences, China \\ ${ }^{2}$ University of Chinese Academy of Sciences, China \\ e-mail: jiangzg@ioz.ac.cn,zhigangjiang@vip.sina.com \\ ${ }^{3}$ Sichuan Normal University, China \\ e-mail:493274915@qq.com
}

Received: 22.04.2019. Revised: 30.05.2019. Accepted: 02.06.2019.

\begin{abstract}
The Przewalski's horse Equus ferus przewalskii was extinct in the wild in the middle of the XX century. Since 1985, the Chinese government has formulated a three-step plan of «the introduction of captive breeding horses - establishing a semi-free population - the restoration of a population in the wild» and carried out the reintroduction of the Przewalski's horse. The first three batches of wild horses were introduced to the Xinjiang Wild Horse Breeding Centre, the Wuwei Endangered Species Breeding Centre and the Beijing Nanhaizi Milu Park. After acclimation and captive breeding, those Przewalski's horses were softly released into the nature reserves in its original ranges in the Mt. Kalamaili Nature Reserve, the Anxi Extreme-arid Desert Nature Reserve and the Dunhuang West Lake Nature Reserve in the new millennium. The released horses are allowed to retain to the large fenced areas at releasing sites with supplementary feed and water. Thus, the wild horses in Chine formed the Xinjiang population, the Wuwei-Dunhuang population and the Beijing-Anxi population. All 23 wild horses that survived in the Anxi Extreme-arid Desert Nature Reserve in 2017 were born after the re-translocation from the Beijing Nanhaizi Milu Park. The number of wild horses in the Beijing Nanhaizi Milu Park increased from two in 1998 to five by the end of 2018. By the end of 2018, there are 413 wild horse descendants from the reintroduced herd in the Xinjiang population. Among them, 89 wild horses were kept in the breeding paddocks of the Xinjiang Wild Horse Breeding Centre, 102 were semi-free ranging in the fenced area of the centre, and 221 re-wild horses lived in the Mt. Kalamaili Nature Reserve. Meanwhile, the Przewalski's horse population in the Dunhuang West Lake Nature Reserve increased to 60. The Wuwei Endangered Animal Breeding Centre released seven wild horses in its Minqin Qinghu Base near the Badanjilin desert. Habitat deterioration, inbreeding, parasitic diseases, wolf predation, infanticide and crossbreeding with domestic horses are the major problems in all Przewalski's horse populations in China. The IUCN Red List of Threatened Species Working Group downgraded the Przewalski's horse to the status of «Endangered» mainly based on the status of wild horses in Mongolia. Nevertheless, the Red List category of the Przewalski's horse in China was still «Extinct in Wild» because the wild horses in these populations still need artificial supplementary feed and water, also need to add new breeding individuals. Thus, a real wild population has not yet been established in China.
\end{abstract}

Key words: Anxi Extreme Arid Desert Nature Reserve, Beijing Nanhaizi Milu Park, captive breeding, Dunhuang West Lake Nature Reserve, Equus ferus przewalskii, Kalamaili Nature Reserve, re-wilding, soft releasing, Wuwei Endangered Animal Breeding Centre, Xinjiang Wild Horse Breeding Centre

The Przewalski's horse Equus ferus przewalskii Poliakov, 1881 was once distributed in the Gobi Desert of Xinjiang, China and Mongolia, along the River Ulungu to Junggar Basin, from the Mountain Beita to the Cobudo Basin of Mongolia, so the wild horse is also known as the Junggar or Mongolian wild horse (Gao, 1984). During the second half of the $19^{\text {th }}$ century, a Russian expedition led by Colonel Nikolai Przewalski explored western China three times. On his second trip home from Xinjiang, China, Colonel Przewalski was presented with a skull and skin of a wild horse, which let Przewalski to return to China and searched for the new animal species. Przewalski claimed they had witnessed and shot wild horses on their third Chinese expedition from Chitai to the River Balykunchusa and Dishui Spring in the Junggar Basin (Przewalski, 1884). However, the Russian explorers, the Grum-Grzhimailo brothers, believed that what Przewalski saw was actually Gobi khulans or dzigettais Equus hemionus hemionus Pallas, 1775 (Grum-Grzhimailo, 1892). In 1881, the Russian zoologist Poliakov named the specimen of the wild horse as the Przewalski's horse Equus przewalskii (Allen, 1938). D.Z. Clemenz, C.E. Büchener and F.E. Falz-Fein were the first persons who tried to capture wild horses in the wild. There were six captures of Przewalski's horses between 1897 and 1903. In 1899, the first Przewalski's horses were transported alive from Asia to Europe. Many captured wild horses died after their captures due to its shy and easily stressed nature while some of the foals died during the 
long journey. The first foal in captivity was born in 1905 . The captive population of the wild horse increased steadily but slowly. At the end of World War II, there were still only 31 wild horses left in the world, of which nine were capable to breed (Boyd \& Houpt, 1994). In the mid-20th century, the Przewalski's wild horse was extinct in its original range (Gao, 1984; IUCN, 2017).

The Foundation for the Preservation and Protection of the Przewalski's Horse was established in the Netherlands in 1978. The IUCN Species Survival Commission established the Equid Specialist Group in 1988. In June 1992, 16 Przewalski's horses were transported to the Hustai National Park and the Takhi Tal site in Mongolia. Since then, more Przewalski's horses have been shipped from European countries to Mongolia. Today, there are more than 500 wild Przewalski's horses in Mongolia, which is the largest wild horse population in the world (Boyd $\&$ Bandi, 2002). The IUCN Red List of Threatened Species downgraded the Przewalski's horse to «Endangered» in 2011 from «Critically Endangered» in 2008.

An initiative for the restoring free ranging and re-wild population of the captive bred Przewalski's horses in the Junggar Basin of Xinjiang was proposed (Wakefield et al., 2002). Since 1985, the Chinese government has carried out the reintroduction operation of Przewalski's horses and formulated a three-step plan of «introduction for captive breeding - establishment of semi-wild free ranging population - restoration of wild population». In 1986, China transferred some Przewalski's horses from Europe for the first time, and established the Xinjiang Wild Horse Breeding Centre in the Jimsar County at the southern margin of the Junggar Basin in Xinjiang (Xia et al., 2014). In 1987, the Wuwei Endangered Animal Breeding Centre brought 18 wild horses from the United States and Germany according to the «Wild Horses Returning Home Plan». In 1988, the Anxi Extreme-arid Desert Nature Reserve in northern Gansu Province which borders Mongolia on its northern border imported ten Przewalski's horses from the UK and maintained the horses in the Beijing Nanhaizi Milu Park first, then relocated the wild horses to Anxi Nature Reserve in 1997. On 28 August 2001, 27 Przewalski's horses from the Xinjiang Wild Horse Breeding Centre were released into the wild in the Mt. Kalamaili Wild Ungulate Nature
Reserve in Xinjiang, marking the beginning of restoration of Przewalski's horse populations within its original habitat (Jiang, 2004). Since then, China's re-wildering Przewalski's horses have frequently appeared in the media and has become the focus of attention of the conservation societies.

We reviewed the reintroduction of the Przewalski's horse in China. Through years of field surveys and literature research, the data of the development and distribution of the population of the Przewalski's horse in China were obtained, and the present status and future prospects of the re-wildering populations of the Przewalski's horse in China were analysed.

\section{Material and Methods}

Since 1994, we have been carrying out research in the Beijing Nanhaizi Milu Park. Przewalski's horses in the park were inspected in October 2018. In addition, we investigated the Xinjiang Wild Horse Breeding Centre in 2003, and the Przewalski's horse released by the Xinjiang Wild Horse Breeding Centre in the Mt. Karamaili Wild Ungulate Nature Reserve in 2003, 2006, 2013, 2014 and 2018, respectively. In 2008, we visited the Dunhuang West Lake Nature Reserve. In 2013, the wild horses in the Anxi Extreme-arid Desert National Nature Reserve and the Wuwei Endangered Animal Breeding Centre were investigated. In February of 2019, we inspected the re-wildering horses in the Mt. Kalamaili Wild Ungulate Nature Reserve in Xinjiang. In March of 2019, we visited the Wuwei Endangered Animal Breeding Centre of the State Forestry and Grassland Bureau. Finally, using literature data, we studied the status of the population of Przewalski's horses reintroduced into China, and analysed the survival prospect of the re-wildering Przewalski's horses by combining the results of the study of The Red List of Chinese Vertebrates (Jiang et al., 2016). The status of the Przewalski's horse in China was assessed during the study.

Gansu Endangered Animal Protection Centre $\left(37.88333^{\circ} \mathrm{N}, 102.716667^{\circ} \mathrm{E}\right)$ with an area of $1816 \mathrm{~km}^{2}$ was established near the River Hongshui, Badanjilin Desert. Since its establishment, the centre has introduced and successfully bred other rare and endangered wild animals, such as the Saiga Saiga tatarica Linnaeus, 1766, wild Bactrian camel Camelus ferus Przewalski, 1878, Khulan Equus hemionus hemionus Pallas 
1775, Takin Budorcas taxicolor Hodgson, 1850, White-lipped deer Cervus albirostris Przewalski, 1883, Tibetan gazelle Procapra picticaudata Hodgson, 1846 and Sichuan golden-haired monkey Rhinopithecus roxellana Milne-Edwards, 1870. In 1987, the centre introduced 18 Przewalski's horses from the United States and Germany for acclimatisation and captive breeding.

The Mt. Kalamaili Wild Ungulates Nature Reserve $\left(44.66667^{\circ} \mathrm{N}, 88.50000^{\circ} \mathrm{E}\right)$, is 14856 $\mathrm{km}^{2}$ in size. The location of the Mt. Kalamaili Wild Ungulates Nature Reserve transects the Altai Prefecture and Chanji Prefecture, Xinjiang. Mt. Kalamaili, the joint part where the Mt. Tianshan and the Mt. Altai meets, is situated in the centre of the Reserve. The Gravel Gobi is found in the eastern part, the Gulban Tungut desert is in the western part, and the Jiangjun Gobi is in the southern part, and low desert dunes are in the northern part of the Reserve. The Reserve is designated for protecting of wild ungulates, which need large areas, such as the khulan, Przewalski's horse, and Goitered gazelle Gazella subgutturosa Güldenstädt, 1780. Since 2001, the Xinjiang Wild Horse Breeding Centre has released wild horses into the Reserve. A monitoring station for monitoring of the re-wildering Przewalski's horses has been established at the Qiaomubaier. Przewalski's horse herds established their territories in the south of the Mt. Kalamaili Wild Ungulates Nature Reserve (Wang Y. et al., 2016).

The Anxi Extreme-arid Desert National Nature Reserve $\left(39.7500^{\circ} \mathrm{N}, 92.7500^{\circ} \mathrm{E}\right)$ was established in June 1987. It was approved by the State Council as a national nature reserve in October 1992. The total area of the Protected Area is $8000 \mathrm{~km}^{2}$. The Anxi Nature Reserve is located at the joint part of the temperate desert, extreme arid desert and typical desert of central Asia, and is also located between the Qinghai-Tibet Plateau Zoogeography Zone and the MongolianXinjiang Desert Zoogeography Zone. Relic ecosystems of the ancient Mediterranean region are still preserved in the Anxi Extreme-arid Desert National Nature Reserve. It is the only Reserve which is designated to protect the extremely arid desert ecosystem in China.

The Dunhuang West Lake National Nature Reserve $\left(39.7500^{\circ} \mathrm{N}, 92.7500^{\circ} \mathrm{E}\right)$, with a total area of $6600 \mathrm{~km}^{2}$, is located in the most western point of the Hexi Corridor, west of the Mogao Grottoes. It borders the Kumtag Desert to the east, near the Lop Nur. This is a nature reserve for protecting of desert ecosystems, oases and wildlife, which plays an important role in water conservation and biodiversity protection in the arid area. The Dunhuang West Lake National Nature Reserve is also a green barrier for protecting the World Cultural Heritage Site - the Dunhuang Mogao Grottoes from desertification.

The Beijing Nanhaizi Milu Park $\left(39.7000^{\circ} \mathrm{N}\right.$, $\left.116.3333^{\circ} \mathrm{E}\right), 0.12 \mathrm{~km}^{2}$ in size in the southern suburbs of Beijing, was formerly a part of the royal hunting park of the Qing Dynasty. It was the place where the type specimen of the milu or Père David's deer Elaphurus davidianus MilneEdwards, 1866 was discovered by Père Armand David from France in 1865. Several milu deer were firstly transported to France, then to other European countries from 1865 to 1900 . From 1894 to 1900, due to the Boxer Wars and floods, the milu deer herd in the royal hunting garden was destroyed and the milu deer went extinct in China. Until 1985, the park reintroduced some milu deer from the Woburn Abbey, United Kingdom (Jiang et al., 2000). In 1985, the Anxi Extreme-arid Nature Reserve imported ten Przewalski's horses from the UK and maintained them in the Beijing Nanhaizi Milu Park. After acclimatisation and captive breeding the horses were relocated to the Anxi Extreme-arid Nature Reserve of Gansu Province, which is one of their original areas.

The Xinjiang Wild Horse Breeding Centre $\left(43.0000^{\circ} \mathrm{N}, 88.5000^{\circ} \mathrm{E}\right)$ covers an area of $20 \mathrm{~km}^{2}$. Since 1985, 24 Przewalski's horses have been transferred to the centre from the UK, the USA and Germany. Since its establishment, the centre has carried out research and experiments on captive breeding, free ranging and rewilding of the reintroduced wild horses. A total of 667 Przewalski's horses of more than six generations were born in the centre, with an average survival rate higher than 90\% (Zhang et al., 1994a,b, 2002). For enriching genetic diversity, the centre imported six more Przewalski's horses from Germany in 2006 to refresh the blood of the population.

\section{Results}

Przewalski's horses currently living in China can be divided into the Xinjiang population, the Beijing-Anxi population and the Wuwei-Dunhuang population, according to their reintroduction and translocation places (Fig. 1). The development and status quo of these three populations are given as follows below. 


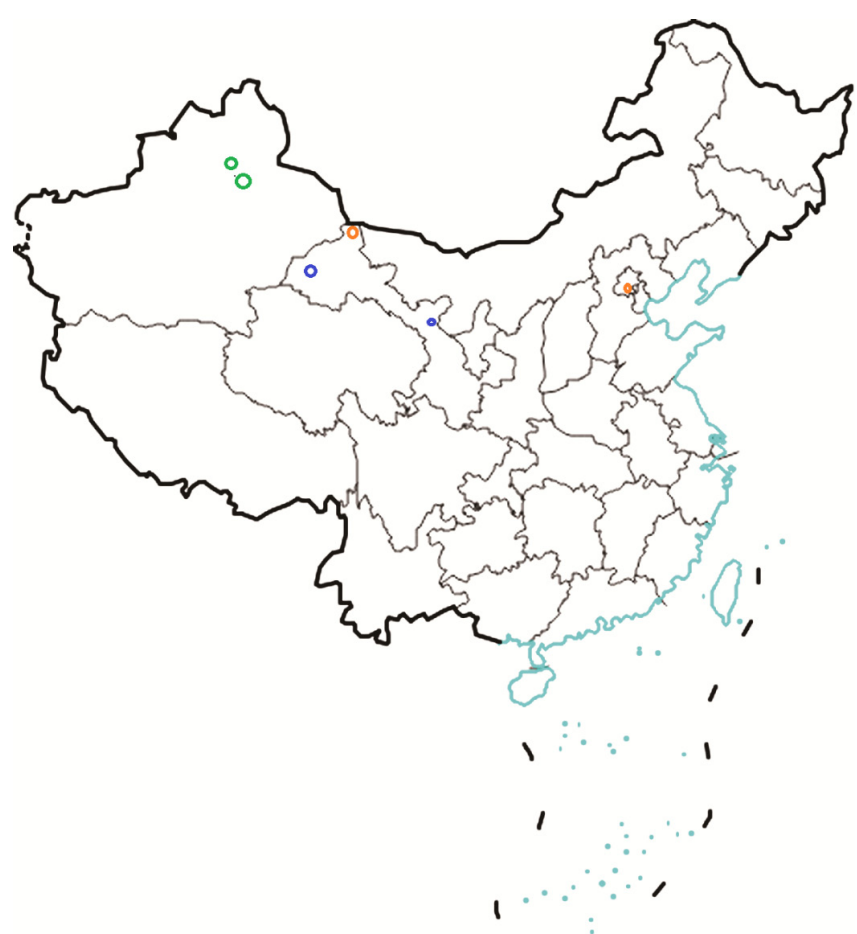

Fig. 1. Populations of the reintroduce- and re-wildering Przewalski's horse in China. Designations: green circles Xinjiang population; blue circles - Wuwei-Dunhuang population; orange circles - Beijing-Anxi population.

\section{The Xinjiang population}

The Xinjiang Wild Horse Breeding Centre is now the world's largest breeding base for the Przewalski's horse. The centre carried out the first wild horse release experiment in China at the end of August 2001. There were 27 wild horses released into the Mt. Kalamaili Wild Ungulate Nature Reserve, which marked launching of the third stage of wild horse restoring in China. Up to now, a total of 130 wild horses have been released into the wild (Fig. 2). After the releasing, the wild horses expanded their range from 120 $\mathrm{km}^{2}$ in 2004 to $660 \mathrm{~km}^{2}$ in 2007 to search for water and forage. However, as the winters are long and harsh in the Jungar Basin, these re-wildering horses still rely on artificial supplemental feed and water during winter. Nevertheless, a preliminary success of re-wildering has been achieved. In 2018, there are 413 wild horses originating from the reintroduced herd in Xinjiang population, including those released into the Mt. Kalamaili Wild Ungulate Nature Reserve. Among them, 89 wild horses were kept in the breeding paddocks of the centre, 102 individuals were ranging semi-free in a fenced area of the centre, and 221 re-wildering Przewalski's horses lived in the Mt. Kalamaili Wild Ungulate Nature Reserve (Fig. 2).

\section{The Wuwei-Dunhuang population}

Arranged by the former Ministry of Forestry, the Wuwei Endangered Animal Breeding Centre has imported 18 Przewalski's horses from the USA and Germany since 1990. On 25 September 2010 and 06 September 2012, the centre carried out two releases of wild horses, respectively. Seven and 21 wild horses were released in a large paddock of the Dunhuang West Lake Nature Reserve, then they were softly released (Fig. 3). The re-wildering horses soon adapted to the local environment. By July 2015, the re-wildering horses gave birth to 16 foals, the total number of the Dunhuang population increased up to 40. By 2018, the Przewalski's horses altogether produced 41 foals, with an average survival rate higher than $95 \%$. The wild horse population in the Dunhuang West Lake Nature Reserve increased to 60. However, the horses still came back to feed with supplementary forage to their paddock. In 2015, after the Minqin Qinghu Base of Wuwei Endangered Animal Breeding Centre was built, the centre released seven wild horses on an experimental basis in the Minqin Qinghu Base near the Badanjilin desert.

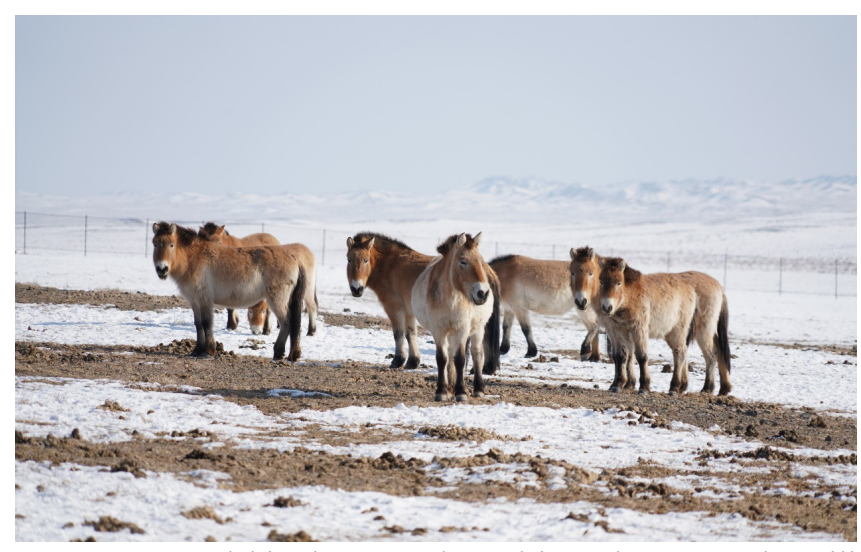

Fig. 2. Przewalski's horses released into the Mt. Kalamaili Nature Reserve from the Xinjiang Wild Horse Breeding Centre (Photo: Z. Jiang).

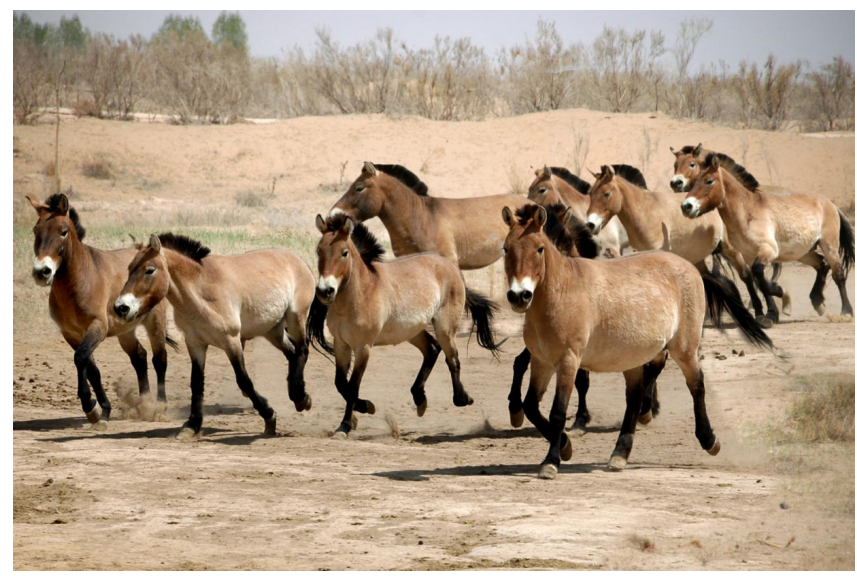

Fig. 3. Przewalski's horses were released into the Dunhuang West Lake Nature Reserve from the Wuwei Endangered Species Breeding Centre (Photo: Wuwei Endangered Species Breeding Centre). 


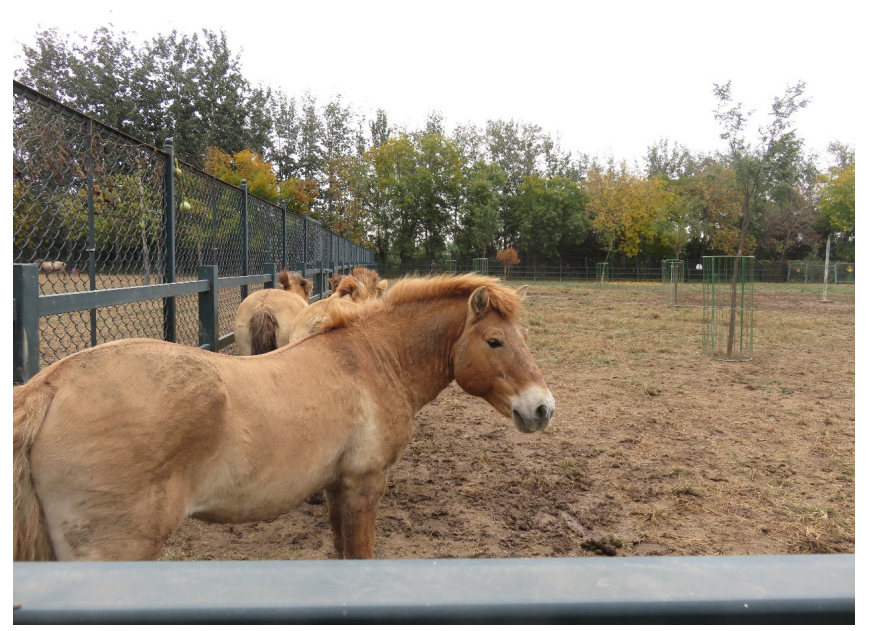

Fig. 4. Przewalski's wild horses in the paddock of Beijing Nanhaizi Milu Park in 2016 (Photo: Z. Jiang).

\section{The Beijing-Anxi population}

In 1997, the Anxi Extreme-arid Desert National Nature Reserve translocated 10 wild horses ( 7 males and 3 females) from the Beijing Nanhaizi Milu Park. After one year of adaptation, foals of the $1^{\text {st }}, 2^{\text {nd }}, 3^{\text {rd }}$ and $4^{\text {th }}$ generations were born out of the translocated horses in 1999, 2004, 2008 and 2012 respectively. Four stallions out of the seven ones introduced in 1997 bred, and all three mares also bred. All 23 wild horses (eight males and 15 females) that survived in 2017 were born after introduction, forming two breeding groups and one bachelor group. These wild horses still rely on artificial supplied feed and drinking water. All of the individuals introduced in 1997 died in 2012. In 1997, in addition to exporting ten wild horses to the Anxi Extreme-arid Desert National Nature Reserve, the Beijing Nanhaizi Milu Park retained two wild horses in the park. By 2018, the number of wild horses in the park increased to five (Fig. 4).

\section{Discussion}

The Przewalski's horse was a mixture feeder on Eurasian steppe but later forced to change to a grazer in arid landscape in central Asia (Kaczensky et al., 2017). In the mid-XX century, after Przewalski's horses went extinct in the wild, it was a consensus in the original range countries, non-governmental organisations and equid conservationists to use the captive-bred Przewalski's horses as the source to restore the wild populations. When China entered the Period of Reform and Opening-up in 1985, the country formulated a threestep plan to restore a wild population of the Przewalski's horse and carried out the reintroductions. Several breeding centres for the Przewalski's horse have been established, and large sized nature reserves have been founded within the original range of the Przewalski's horse (Xia et al., 2014). More important, China has implemented a «soft release» strategy of the captive bred wild horses in the Junggar basin, the Dunhuang desert and the Anxi desert, the released wild horses have gradually adapted to the local environment. The released wild horses have a seasonal reproduction characteristic, $71 \%$ of the foals were born between May and June in the Xinjiang Wild Horse Breeding Centre, thus after releasing. The peak of foaling of wild horses was significantly delayed after releasing, possibly due to the change of environment and food resources. They also shown group fidelity, as the time passed after releasing, the wild horses were less and less likely to switch from herds (Chen, 2007). However, the three wild horse populations in China still face the following problems.

\section{Habitat deterioration}

The habitats of the last Przewalski's horses observed in the wild in the XX century were arid deserts with sparse vegetation of low primary productivity. At present, local nomadic herders living within the former range of Przewalski's horse practice seasonal rotation herding regime, using areas of the wild horse as the winter pasture for their livestock. Furthermore, construction of the national highway No. 216 through the Mt. Kalamaili Nature Reserve and mining affected the survival of the released wild horses. The rewildering Przewalski's horses faced the danger of road-killing by large vehicles. From August to October 2007, five wild horses were killed by passing vehicles, including two females and three foals (Chen et al., 2007). These problems have aroused attention and measures were taken to resolve the problems. The Przewalski's horses were moved to a remote area and all mines were shut down. Water is a key factor for wildlife in arid areas; the survival of wildlife depends on the availability of water and its quality. Zhang et al. (2014) sampled water sources in the range of the wild horse in the Mt. Kalamaili Nature Reserve. The analysis showed that fluorides, sulphite ions and sodium in these sampled water sources exceeded the standard of drinkable water by $60 \%, 24 \%$, and $28 \%$ respectively. In the future, attention should be paid to the high fluoride, sulphite ion and sodium contents in the water holes. The Dunhuang West Lake National Nature Reserve is facing with the problems of falling ground water level, shrinking water bodies, swamping of lake and re-activation of the once fixed sand dunes (Wang et al., 2012).

\section{Inbreeding problem}

Now, the ratio of male to female in the Wuwei Endangered Animal Breeding Center is 4/1; there are more males than females. An unbalanced sex ratio, 
infertility of mares, improper management and missing the breeding season affect the reproductive rate of captive-bred wild horses (Zhang et al., 1990). In addition, abortion and sterility decreased the reproduction rate in wild horses (Zhang et al., 2002). From 2002 to 2006 , totally 24 wild horses were bred in the wild of the Mt. Kalamaili Nature Reserve, with an average reproductive rate of $39 \%$ and an average reproductive survival rate of $69 \%$. Frequent replacements of harem stallions during a breeding season resulted in a non-conception of most mares, which was the main factor affecting the reproduction rate of the Przewalski's horses (Chen, 2007). Liu et al. (2014) evaluated genetic diversity in the reintroduced Przewalski's horse in China using genetic and pedigree data. They found out that more than 100 individuals retain approximately $90 \%$ of its current genetic diversity which is already depauperate. They also discovered a higher level of diversity in the captive Przewalski's horse populations than the reintroduced population in China. Both pedigree and microsatellite data showed a high level inbreeding which was generally higher in the reintroduced population. And genetic differentiation was detected among the wild horse populations presumably due to isolation.

\section{Parasitic diseases}

The interspecific transmission of parasitic diseases is related to the phylogenetic relationship and habitat sharing (Stephens et al., 2019). The infection with gastric botflies Gastrophilus spp. was found in both domestic and wild equine species in steppe and desert steppe areas of central Asia (Wang W. et al., 2016). For a long time, endoparasitic diseases in the wild horse were not well noticed and treated (Li et al., 2007). Xu et al. (1995) first expelled parasites from the Przewalski's horses with anthelmintics and found that the wild horses shared 15 species of parasites with domestic horses. Zhang et al. (2007) found that Parascaris equorum Goeze, 1782 was the most common parasite in captive-bred wild horses, and almost all individuals were infected. The endoparasites in wild horses were mainly Gastrophilus spp. There were Gastrophilus in the habitat of re-wildering Przewalski's horses. Thus, it is necessary to periodically exorcise the endogenous parasites in wild horses. Diseases and injuries were the main causes of death in Przewalski's horses in the Anxi Nature Reserve. Nine wild horses introduced in the Reserve died due to diseases and five died due to injuries, accounting for $27 \%$ and $15 \%$ of the total mortality of the wild horses respectively (Pei et al., 2018).

\section{Wolf predation and infanticide}

Predation by wolves Canis lupus Linnaeus, 1758 and infanticide by harem stallions are among the mortality causes of Przewalski's horses. In the Anxi Nature Reserve, 12 wild horses were preyed on by wolves, accounting for $35 \%$ of the total deaths (Pei et al., 2018). Wild horses are also killed by wolves in the Mt. Kalamaili Nature Reserve. In 2012, Dong et al. (2015) studied the feeding habits of wolves in summer and autumn by using a faecal analysis method. They found that the relative frequencies of plants, gerbils and insects in wolves' scats were $30.19 \%, 19.35 \%$ and $13.55 \%$, respectively. The relative frequencies of khulans and goitered gazelles in the wolf diet were $1.94 \%$ and $3.10 \%$, while there were $1.42 \%$ of remnants of Przewalski's horses in the wolves' scats. However, Wang et al. (2014) found that wolves are mainly active at night from April to June and from September to November, based on the photos taken by infrared camera set up in the Karamori Mountain Ungulate Nature Reserve. The average mortality rate of newborn foals in the Mt. Kalamaili Nature Reserve was $25 \%$, of which $83.3 \%$ were caused by infanticide by harem stallions (Chen et al., 2007). In the Anxi Nature Reserve, two foals were killed by harem stallions, accounting for $6 \%$ of the total deaths. One foal died from dystocia and three foals died from weakness, accounting for $11 \%$ of the mortality rate (Pei et al., 2018).

The risk of crossbreeding with domestic horse

Przewalski's horses released into the wild are also at risk of crossbreeding with domestic horses, especially when the stallions lose the fight for competing the position of a harem stallion during the breeding season. The losers will look for domestic mares to mate with. Thus, there is a risk of genetic mix-up. Kazakh nomadic herdsmen use the desert grasslands in the Mt. Karamaili Nature Reserve as winter pastures and use domestic horses as their beast of burden. Their horses together with other livestock competing forage of rewildering Przewalski's horses. The conflict between livestock and wild horses is escalating, which threatens the survival and genetic purity of wild horses. At present, the only measure is to try to isolate the breeding population of wild horses during the breeding season.

\section{Conclusions}

As an original area of the Przewalski's horse, China is joining the world-wide endeavour to restore the species in the wild. Three main populations of the Przewalski's horse have been established since 1985, and the reintroduced horses have softly released into wild: the released horses are allowed to retain to the 
large fenced areas at releasing sites to feed on supplementary feed and water. In such a term, the wild horses in Chine are not completely self-sustainable in nature; the rewilding process is still ongoing in the country.

We conducted the China Red List of Vertebrates Assessment from 2013 to 2015. Although China has established the Xinjiang population, the WuweiDunhuang population and the Beijing-Anxi population of Przewalski's horses, these populations still need artificially supplementary feed and water, and we also need to add new breeding individuals. As a true wild population has not yet been established, the red list category of the Przewalski's horse in China was still «Extinct in Wild». China and the rest of the world still have a long way to go for restoring the Przewalski's horse in the wild.

\section{Acknowledgements}

We received help during the study from the Department of Wild Fauna and Flora, State Forestry and Grassland Bureau, provincial wildlife management authorities of Xinjiang, Gansu and Beijing, as well as from the Mt. Kalamaili Nature Reserve, the Anxi Extreme-arid Desert Nature Reserve and the Dunhuang West Lake Nature Reserve. The study was supported by the Strategic Leading Science and Technologic Special Project of the Chinese Academy of Sciences (Type A, No. XDA19050204) and the Basic Science Special Project of Ministry of Science and Technology of China (2013FY110300).

\section{References}

Allen G.M. 1938. The Mammals of China and Mongolia. Vol. 4 (Part 1). New York. 1280-1287.

Boyd L., Houpt, K.A. (Eds). 1994. Przewalski's Horse: The History and Biology of an Endangered Species. New York: State University of New York Press. 313 p.

Boyd L., Bandi, N. 2002. Reintroduction of takhi to Hustai National Park, Mongolia: time budget and synchrony of activity pre- and post-release. Applied Animal Behaviour Science 78(2): 87-102. DOI: 10.1016/S0168-1591(02)00088-6

Chen J., Hu D., Cao J., Li K., Lv Q. 2007. Male infanticide behaviour of Equus przewalskii and its impact on wild horse reintroduction. Chinese Bulletin of Biology 42: 6-8. [In Chinese]

Dong T., Chu H., Liu D., Ma J., Zhang J., Ge Y, Bu L. 2015. Food habits of wolves (Canis lupus) during summer and autumn in the Mt. Kalamaili Ungulate Nature Reserve, Xinjiang. Arid Zone Research 32(3): 512-517. [In Chinese]

Gao X. 1984. Preliminary report of Przewalski horse. Arid Zone Research 1(1): 71-72.

Grum-Grzhimailo G.E. 1892. The wild horse (Equus przewalskii). From the diary of a travel to Chine in 1889 1890. Niva 17: 374-382. [In Russian]

IUCN. 2017. From extinction to free ranging by successful reintroduction. Available from: https://www.iucn.org/ news/commission-ecosystem-management/201803/ extinction-free-ranging-successful-reintroduction
Jiang Z. 2004. Wild Horse (Equus przewalskii). Chinese Journal of Zoology 39: 100-101. [In Chinese]

Jiang Z., Feng Z., Yu C., Zhang L., Xia J., Ding Y. Lindsay N. 2000. Reintroduction and Recovery of Père David's Deer in China. Wildlife Society Bulletin 28(3): 681-687. DOI: $10.2307 / 3783620$

Jiang Z., Jiang J., Wang Y., Zhang E., Zhang Y., Li L., Xie F., Cai B., Cao L., Zheng G., Dong L., Zhang Z., Ding P., Luo Z., Zheng, G., Ding C., Ma Z., Tang S., Cao W., Li C., Hu H., Ma Y., Wu Y., Wang Y., Zhou K., Liu S., Chen Y., Li J., Feng Z., Wang Y., Wang B., Li C., Song X., Cai L., Zang C., Zeng Y., Meng Z., Fang H., Ping X. 2016. Red List of China's Vertebrates. Biodiversity Science 24(5): 500-551. DOI: 10.17520/biods.2016076 [In Chinese]

Kaczensky P., Šturm M.B., Sablin M.V., Voigt C.C., Smith S., Ganbaatar O., Balint B., Walzer C., Spasskaya N.N. 2017. Stable isotopes reveal diet shift from pre-extinction to reintroduced Przewalski's horses. Scientific Reports 7(1): 5950. DOI: 10.1038/s41598-017-05329-6

Li K., Wu Z., Hu D., Cao J., Wang C. 2007. A report on new causative agent (Gasterophilus spp.) of the myiasis of Przewalski's horse occurred in China. Chinese Journal of Animal and Veterinary Sciences: 38(8): 837-840. [In Chinese]

Liu G., Shafer A., Zimmermann W., Hu D., Wang W., Chu, H., Cao J., Zhao C. 2014. Evaluating the reintroduction project of Przewalski's horse in China using genetic and pedigree data. Biological Conservation 171: 288-298. DOI: 10.1016/j.biocon.2013.11.022

Pei P., Wang L., Shao Y., Shi C., Yang Y., Bai X. 2018. Reintroduction Przewalski's horse's breeding success and population viability analyses in Anxi National Nature Reserve. Acta Theriologica Sinica 38(2): 128-139. DOI: 10.16829/j.slxb.150117 [In Chinese]

Przewalski N. 1884. Reisen in Tibet und am oberen Lauf des Gelben Flusses in den Jahren 1879 bis 1880. Jena: Stein Nordheim. 269 p.

Stephens P.R., Altizer S., Ezenwa V.O., Gittleman J.L., Barbara E.M., Huang H., Pappalardo P. 2019. Parasite sharing in wild ungulates and their predators: effects of phylogeny, range overlap, and trophic links. Journal of Animal Ecology. DOI: 10.1111/1365-2656.12987.

Xu X. Huang Y., Hu J., Qi C. 1995. Parasites and their repelling of Equus przewalskii in Xinjiang. Chinese Journal of Veterinary Medicine 7: 16. [In Chinese]

Wakefield S., Knowles J., Zimmermann W., Dierendonck M.V. 2002. Status and Action Plan for the Przewalski's Horse (Equus ferus przewalskii). In: P.D. Moehlman (Ed.): Equids: Zebras, Asses and Horses. Cambridge, United Kingdom: IUCN Publications Services Unit. P. 82-92.

Wang H., He Z., Wang H., Niu Y. 2012. Study on survival status of reintroduced Equus przewalskii in Dunhuang West Lake National Nature Reserve. Journal of Gansu Forestry Science and Technology 37: 44-46. [In Chinese]

Wang Y., Chu H., Han L., Ge Y., Tao Y., Bu L. 2014. Activity of Canis lupus in the Karamori Mountain Ungulate Nature Reserve based on trap technique of infrared camera. Arid Zone Research 31: 771-778. [In Chinese]

Wang W., Xiao S., Huang H., Li K., Zhang D., Chu H., Guo Y., Gao W. 2016. Diversity and infection of Gasterophi- 
lus spp. in Mongol-Xinjiang Region and Qinghai Tibet Region. Scientia Silvae Sinicae 52(2): 134-139. DOI: 10.11707/j.1001-7488.20160217 [In Chinese]

Wang Y., Chu H., Han L., Tao Y., Bu L., Liu Z., Jiang Z. 2016. Factors affecting the home range of reintroduced Equus przewalskii in the Mt. Kalamaili Ungulate Nature Reserve. Acta Ecologica Sinica 36(2): 545-553. DOI: 10.5846/stxb201402090224 [In Chinese]

Xia C., Cao J., Zhang H., Gao X., Yang W., David B. 2014. Reintroduction of Przewalski's horse (Equus ferus przewalskii) in Xinjiang, China: The status and experience. Biological Conservation 177: 142-147. DOI: 10.1016/j.biocon.2014.06.021

Zhang J., Yan H., Ma C. 1990. 1987-1990 Equus przewalskii Breeding Report. Chinese Journal of Wildlife 20: 27-29. [In Chinese]
Zhang H., Sun L., Cao J. 2002. The Breeding status of captive przewalskii horse in Xinjiang. Chinese Journal of Zoology 37: 70-72. [In Chinese]

Zhang H., Li K., Chen J., Hu D. 2007. Monitoring of Equus przewalskii parasites. Gansu Animal and Veterinary Sciences 27: 94-96. [In Chinese]

Zhang J., Ma C., Yan H. 1994a. Main measures to improve the reproduction rate of Equus przewalskii under captive conditions. Chinese Journal of Wildlife 24: 35-36. [In Chinese]

Zhang J., Ma C., Yan H. 1994b. Some understanding on improving the reproduction rate of Equus przewalskii under captive conditions. Chinese Journal of Zoology 29: 54-57. [In Chinese]

Zhang Y., Zhang F., Cao J., Hu D., Chu H. 2014. Status and quality of water sources in the Kalamari Ungulate Nature Reserve - a case study in the released area of Equus przewalskii. Arid Zone Research 31: 665-671. [In Chinese]

\title{
ВОССТАНОВЛЕНИЕ ЛОШАДЕЙ ПРЖЕВАЛЬСКОГО В КИТАЕ: СТАТУС КВО И ПЕРСПЕКТИВЫ
}

\author{
Чж. Цзян ${ }^{1,2}$, Х. Цзун ${ }^{3}$ \\ ${ }^{1}$ Институт зоологии, Академия наук Китая, Китай \\ ${ }^{2}$ Университет Китайской академии наук, Китай \\ e-mail:jiangzg@ioz.ac.cn,zhigangjiang@vip.sina.com \\ ${ }^{3}$ Сычуаньский педагогический университет, Китай \\ e-mail:493274915@qq.com
}

Лошадь Пржевальского Equus ferus przewalskii вымерла в дикой природе в середине XX в. С 1985 г. Правительство Китая разработало трехэтапный план «интродукция животных, родившихся в неволе - создание полувольной популяции - восстановление популяции в природе» и осуществило операцию по реинтродукции диких лошадей Пржевальского. Первые три партии диких лошадей были завезены в Синьцзянский центр разведения диких лошадей, Центр разведения исчезающих видов Вувей и в Пекинский Парк Наньхайцзы Милу. В новом тысячелетии после акклиматизации и разведения в неволе эти лошади Пржевальского были выпущены «мягким методом» в природные заповедники в пределах их первоначального ареала: природный заповедник Каламаили, заповедник экстремально-засушливых пустынь Анси и заповедник западного озера Дуньхуан. Выпущенные лошади могут оставаться на больших огороженных участках в местах выпуска с дополнительным кормом и водой. Таким образом, дикие лошади в Китае сформировали популяцию Синьцзяна, популяцию Вувей-Дуньхуан и популяцию Пекин-Анси. Все 23 дикие лошади, которые выжили в заповеднике экстремально-засушливых пустынь Анси в 2017 г., родились после переселения из пекинского парка Наньхайцзы Милу. Число диких лошадей в пекинском парке Наньхайцзы Милу увеличилось с двух в 1998 г. до пяти к концу 2018 г. К концу 2018 г. в реинтродуцированном табуне в Синьцзяне насчитывается 413 особей диких лошадей. Из них 89 лошадей содержались в загонах для разведения Синьцзянского центра по разведению диких лошадей. 102 особи были полувольными в пределах огороженной территории центра. И 221 реинтродуцированная лошадь жила в Каламалинском заповеднике. Тем временем популяция лошадей Пржевальского в природном заповеднике западного озера Дуньхуан увеличилась до 60 особей. Центр разведения исчезающих видов Вувэй выпустил семь диких лошадей на своей базе Миньцин Цинху около пустыни Баданджилин. Ухудшение среды обитания, инбридинг, паразитарные болезни, хищничество волков, инфантицид и скрещивание с домашними животными являются основными проблемами у всех лошадей Пржевальского в Китае. Рабочая группа Красного списка угрожаемых видов МСОП понизила охраняемую категорию дикой лошади Пржевальского до «Critically Endangered», главным образом, исходя из статуса диких лошадей в Монголии. Тем не менее, категория Красного списка МСОП для лошади Пржевальского в Китае все ещё является «Extinct in WIld», поскольку дикие лошади в этих популяциях по-прежнему нуждаются в искусственном дополнительном питании и воде, также необходимо добавлять новых способных к размножению особей. Таким образом, настоящая дикая популяция ещё не создана в Китае.

Ключевые слова: Equus ferus przewalskii, заповедник западного озера Дуньхуан, заповедник Каламайли, заповедник экстремально засушливых пустынь Анси, мягкий выпуск, Пекинский парк Наньхайцзы Милу, разведение в неволе, реинтродукция, Синьцзянский центр разведения диких лошадей, Центр разведения исчезающих видов Вувей 